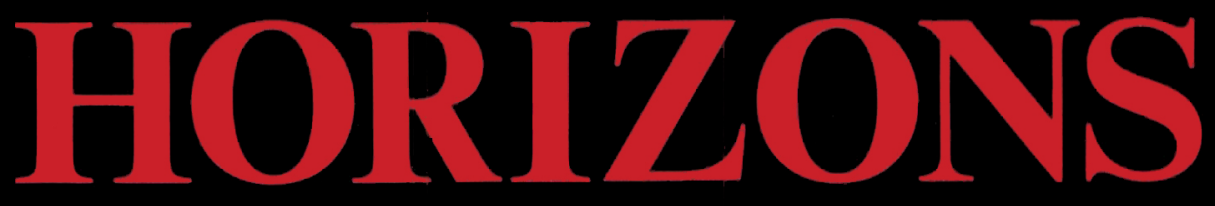

Volume 23

Fall, 1998

Number 2

\title{
ARTICLES
}

Peter C. Phan, To Be Catholic or Not to Be: Is It Still the Question? Catholic Identity and Religious Education Today

Kevin Hogan, Entering into Otherness: The Postmodern Critique of the Subject and Karl Rahner's Theological Anthropology

Theresa Sanders, Remarking the Silence: Prayer after the Death of God

Bradley Malkovsky, Swami Vivekananda and Bede Griffiths on Religious Pluralism: Hindu and Christion Approaches to Truth

\section{CREATTVE TEACHING}

John K. Downey, Postmodernity and Pedagogy: Connecting the Dots

\section{EDITORIAL ESSAYS}

Terrence W. Tilley, Practicing History, Practicing Theology

Frans Jozef van Beeck, S.J., $A$ Very Explicit Te Deum: A Spiritual Exercise, To Help Overcome

Trinitarian Timidity

\section{REPORT OF THE COLLEGE THEOLOGY SOCIETY}

\section{REVIEW SYMPOSIUM}

Pamela Kirk's Sor Juana Inés de la Cruz: Religion, Art, and Feminism Four Perspectives: Lawrence S. Cunningham, Barbara E. Reid, O.P., Gustavo Benavides, Carole A. Myscofski

Author's Response: Pamela Kirk

Plus Reviews of 22 Books 


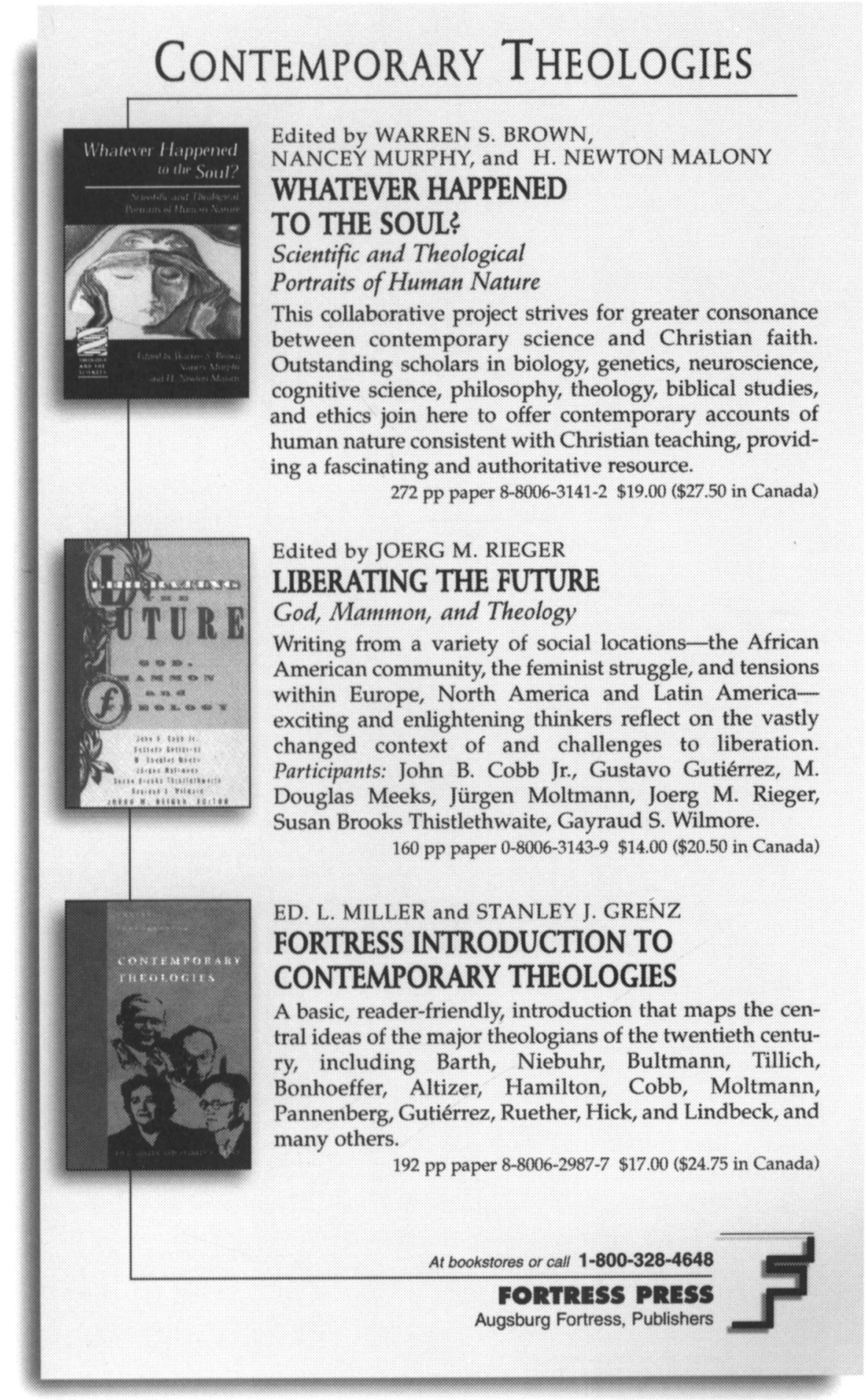




\section{HORIZONS}

\section{The Journal of the College Theology Society}

Published at Villanova University

Volume 25

Fall, 1998

Number 2

\section{ARTICLES}

To Be Catholic or Not to Be: Is It Still the

Question? Catholic Identity and

Religious Education Today

Peter C. Phan 159

Entering into Otherness: The Postmodern

Critique of the Subject and Karl

Rahner's Theological Anthropology

Kevin Hogan 181

Remarking the Silence: Prayer after

the Death of God

Theresa Sanders 203

Swami Vivekananda and Bede Griffiths

on Religious Pluralism: Hindu and

Christian Approaches to Truth

Bradley Malkovsky 217

\section{CREATIVE TEACHING}

Postmodernity and Pedagogy:

Connecting the Dots

John K. Downey 238

\section{EDITORIAL ESSAYS}

Practicing History, Practicing Theology

Terrence W. Tilley 258

A Very Explicit Te Deum: A Spiritual

Exercise, To Help Overcome

Trinitarian Timidity

Frans Jozef van Beeck, S.J. 276

REPORT OF THE COLLEGE THEOLOGY SOCIETY 292

\section{REVIEW SYMPOSIUM}

Pamela Kirk's Sor Juana Inés de Ia Cruz:

Religion, Art, and Feminism

Four Perspectives

Lawrence S. Cunningham 295

Barbara E. Reid, O.P. 300

Gustavo Benavides 301

Carole A. Myscofski 303

Author's Response Pamela Kirk 306

\section{BOOK REVIEWS}

Angelo Di Berardino and Basil Studer, eds.,

History of Theology, Vol. 1:

The Patristic Theology Maureen A. Tilley 
Michael Himes, Ongoing Incarnation: Johann

Adam Möhler and the Beginnings of

Modern Ecclesiology

Dennis M. Doyle 314

Ian Ker, ed., Newman and Conversion Walter E. Conn 315

Charles R. Morris, American Catholic:

The Saints and Sinners Who Built

America's Most Powerful Church Rodger Van Allen 316

Gail Porter Mandell, Madeleva: A Biography Mary Jo Weaver 318

Georges Passelecq and Bernard Suchecky,

The Hidden Encyclical of Pius XI Donald J. Dietrich 319

Giuseppe Alberigo, ed., History of Vatican II,

Vol. 1: Announcing and Preparing Vatican

Council II toward a New Era in Catholicism Carmel E. McEnroy

Thomas Franklin O'Meara, O.P.,

Thomas Aquinas, Theologian Michael J. Dodds, O.P. 321

William P. Loewe, The College Student's

Introduction to Christology Michael L. Cook, S.J.

Stephen T. Davis, Daniel Kendall, S.J., and

Gerald O'Collins, S.J., The Resurrection:

An Interdisciplinary Symposium on

the Resurrection of Jesus Kenan B. Osborne, O.F.M. 323

Reginald Stackhouse, The End of the World?

A New Look at an Old Belief Loretta M. Devoy 324

Jürgen Moltmann, ed., How I Have Changed:

Reflections on Thirty Years of Theology John Jaeger 326

Mary Catherine Hilkert, Naming Grace: Preaching

and the Sacramental Imagination Jane Kopas

Penelope J. Ryan, Practicing Catholic: The

Search for a Liveable Catholicism Brennan R. Hill 328

Ellen M. Leonard, Creative Tension: The

Spiritual Legacy of Friedrich von Hügel William $M$. Thompson

Eilish Ryan, Rosemary Haughton:

Witness to Hope Elizabeth E. Carr

Larry L. Rasmussen, Earth Community,

Earth Ethics Theodore W. Nunez

Edward Stevens, Developing Moral Imagination:

Case Studies in Practical Morality John M. Ballweg 334

Joseph Flanagan, Quest for Self-Knowledge:

An Essay in Lonergan's Philosophy Michael Vertin 335

Patrick W. Carey and Earl C. Muller, S.J., eds.,

Theological Education in the Catholic

Tradition: Contemporary Challenges;

Denise Lardner Carmody, Organizing

a Christian Mind: A Theology of Higher

Education; and Marcel J. Dumestre,

A Church at Risk: The Challenge of

Spiritually Hungry Adults

Florence C. Bourg

336 
Contents

BOOKS RECEIVED _...................................................................... $\quad 340$

INDEX

Copyright (c) 1998 College Theology Society

Printed in the United States of America

\section{ERRATUM}

In $25 / 1$ the third sentence of the second full paragraph on page 63 should read:

Clearly, the answer is "no," and the implication is that the divinehuman relationship depends, above all, on commitment to an ethical life, not on the accouterments of an established cult. 


\section{HORIZONS}

\section{The Journal of the College Theology Society}

Horizons, The Journal of the College Theology Society is published biannually in Spring and Fall at Villanova University, Villanova, PA 19085.

Yearly subscription: individual $\$ 16.00$, institutional $\$ 40.00$. Send remittance, payable to Wilfrid Laurier University Press, to Wilfrid Laurier University Press, Wilfrid Laurier University, Waterloo, Ontario, Canada N2L 3C5. Changes of address should also be sent to this address. Horizons is automatically received through membership in the College Theology Society.

Manuscripts, editorial and business correspondence, book reviews, advertising copy, and orders for single issues (individual $\$ 8.00$, institutional \$20.00) should be addressed to The Editor, Horizons, Journal of the CTS, Villanova University, Villanova, PA 19085.

In submitting manuscripts, please send four clear copies. Author's name should appear only on an unpaginated cover sheet, with address and essay's title. No other identifying reference to author should appear on the manuscript. All references to author's work in text or notes should be in the third person. Essay's title should appear at top of first page of text. Notes should be placed on separate sheets at end. Full double spacing should be used throughout, including indented quotations and notes. Top, bottom, and right-hand margins should be at least one inch; left-hand margins at least one-and-a-half. Manuscripts should be accompanied by an abstract of one hundred fifty words or less and an author vita of one hundred words or less. Authors should state that the manuscript will not be submitted to another journal until Horizons' evaluation is completed. Manuscripts will be returned if postage is supplied.

Articles appearing in Horizons are abstracted and indexed in: The Catholic Periodical and Literature Index; Guide to Social Science and Religion in Periodical Literature; Index to Religious Periodical Literature; New Testament Abstracts; Religious and Theological Abstracts; and Social Science Citation Index. Articles are indexed in Religion Index One: Periodicals; book reviews indexed in Index to Book Reviews in Religion. Horizons is available in microform from University Microfilms International, 300 North Zeeb Road, Department P.R., Ann Arbor, MI 48106.

\section{(}

The College Theology Society is a professional organization of college and university professors of religion in the United States and Canada.

The purpose of the College Theology Society is to improve the quality of the teaching of religion: by stimulating and sharing scholarly research; by developing programs of theology and religious studies which meet student needs and interests; and by exploring, evaluating, and encouraging effective ways of teaching which are interdisciplinary and ecumenical.

Annual membership dues in the Society are $\$ 40.00$ (Full Professional or Associate), $\$ 45.00$ (Joint Professional for husband and wife), and \$20.00 (Graduate Student). Membership in the Society includes a subscription to Horizons. Contact Gary Macy, Theological and Religious Studies Department, University of San Diego, Alcalá Park, San Diego, CA 92110. 


\section{EDITOR}

Walter E. Conn

Villanova University

\section{ASSOCIATE EDITORS}

Lisa Sowle Cahill

Boston College

Denise Lardner Carmody

Santa Clara University

Anne Carr

The University of Chicago

Bernard Cooke Incarnate Word College

Lawrence S. Cunningham

University of Notre Dame

Charles E. Curran

Southern Methodist University

Margaret A. Farley

Yale Divinity School

Elisabeth Schüssler Fiorenza

Harvard Divinity School

Francis Schüssler Fiorenza

Harvard Divinity School
Mary Ann Hinsdale College of the Holy Cross

Elizabeth A. Johnson Fordham University

Paul F. Knitter Xavier University

Pheme Perkins

Boston College

Sandra M. Schneiders, I.H.M. Jesuit School of Theology at Berkeley

William M. Shea

Saint Louis University

Gerard S. Sloyan

The Catholic University of America

William M. Thompson

Duquesne University

David W. Tracy

University of Chicago

Mary Jo Weaver

Indiana University

BOOK REVIEW EDITOR

Joann Wolski Conn

Neumann College

BUSINESS EDITOR

Anne McGuire

Haverford College

EDITORIAL ASSISTANT

Irene C. Noble 


\section{HORIZONS}

\section{The Journal of the College Theology Society}

A journal exploring developments in Catholic theology, the total Christian tradition, human religious experience, and the concerns of creative teaching from the college and university environment.

This fall our articles range from Catholic identity to a Hindu and Christian comparison, with a couple of postmodern markers along the way. Peter Phan starts us off with his reflections on religious education: "To Be Catholic or Not to Be: Is It Still the Question?" Kevin Hogan examines postmodernism, the subject, and Rahner's anthropology in "Entering into Otherness." Theresa Sanders considers prayer in a postmodern key in "Remarking the Silence." And Bradley Malkovsky focuses on Hindu and Christian approaches to truth in "Swami Vivekananda and Bede Griffiths on Religious Pluralism."

Postmodernity is featured again in John Downey's Creative Teaching essay: "Postmodernity and Pedagogy: Connecting the Dots." Our Editorial Essay section has two very different pieces. In "Practicing History, Practicing Theology," Terry Tilley distills the essence of his provocative 1998 CTS Presidential Address given at St. Louis University. And Frans Jozef van Beeck uses his poetic powers to help us overcome Trinitarin Timidity in "A Very Explicit Te Deum." This issue also includes the 1998 Annual Report of the College Theology Society. The Review Symposium features Pamela Kirk's Sor Juana Inés de la Cruz: Religion, Art, and Feminism. The author responds to the comments of Lawrence Cunningham, Barbara Reid, Gustavo Benavides, and Carole Myscofski. Reviews of twenty-two recent books complete the picture.

Finally, I am delighted to announce that two longtime friends of Horizons are joining the Editorial Board: Mary Ann Hinsdale of the College of the Holy Cross, and David Tracy of the University of Chicago.

—Walter E. Conn 